\title{
Substrate exploitation and resistance to biotic disturbance in the brachiopod Terebratalia transversa and the bivalve Pododesmus macrochisma
}

\author{
Adam Tomašových* \\ Geological Institute, Slovak Academy of Sciences, Dúbravská cesta 9, 84005 Bratislava, Slovakia
}

Present address: University of Chicago, Department of Geophysical Sciences, 5734 S. Ellis Ave., Chicago, Illinois 60637, USA

\begin{abstract}
To test the hypothesis that epifaunal bivalves are more resistant to biotic disturbance than brachiopods, I evaluated abundances and body size of the brachiopod Terebratalia transversa and the anomiid bivalve Pododesmus macrochisma, which co-occur in the San Juan Islands (Washington State, USA, eastern Pacific). The proportion of bare space correlated with intensity of biotic disturbance had negative effects and surface rugosity had positive effects on abundance of $T$. transversa. Both rugophilic settlement and post-settlement mortality of juveniles due to biotic disturbance restrict $T$. transversa to crevices and complex substrates formed by solitary ascidians and giant barnacles. Its juveniles are under-represented on flat substrates, implying lower survivorship than in crevices, where juveniles are common. Abundance of the byssally-cemented bivalve P. macrochisma is negatively affected by rugosity and does not decrease with increasing bare space. P. macrochisma size patterns do not differ between crevices and flat substrates. Flat valves and high post-settlement mobility probably increase its juvenile survivorship under grazing pressure. $T$. transversa is not able to re-attach after settlement and is thus less resistant to grazing effects than $P$. macrochisma. This study supports the hypothesis that brachiopods are more negatively affected by biotic disturbance than epibyssate bivalves. Although brachiopods can be less preyed upon by carnivorous predators than epibyssate bivalves, $T$. transversa is affected more negatively by grazing than P. macrochisma. The evolutionary decline of brachiopod abundance in shallow habitats may represent responses to a heavy pressure on juveniles by grazers that evolved during the Mesozoic.
\end{abstract}

KEY WORDS: Bivalve mollusk · Brachiopod · Disturbance $\cdot$ Grazing impact $\cdot$ Substratum $\cdot$ Subtidal marine macrobenthos

\section{INTRODUCTION}

Although some brachiopods from temperate and polar regions occupy open, non-cryptic substrates (Noble et al. 1976, Grange et al. 1981), present-day habitats usually harbor small-sized brachiopods that are restricted to cryptic environments (Logan 1975). The restriction of brachiopods to safe places or refuges in modern hardbottom habitats is generally ascribed either to high carnivorous predation pressure (Harper \& Wharton 2000, Aberhan et al. 2006, Gili et al. 2006), or to high competition pressure, owing to the evolution of mollusks and other groups with superior abilities to compete for space and food (Thayer 1985, Bush et al. 2007, NovackGottshall 2007). The survivorship of brachiopods in present-day habitats thus may depend on abundance of prey and competitive refuges, which generally correlates with substrate complexity (Hixon \& Menge 1991), and on efficiency in resource utilization and resistance to consumer pressure (Peck 1996, Peck et al. 2005). However, the terebratulid brachiopod Terebratalia transversa, which is a relatively common inhabitant of shallow, cool-temperate, rocky bottom habitats of the San Juan Islands (Washington State, USA, eastern Pacific), is 
rarely preyed on. Sea stars, crabs, and predatory gastropods occupying either intertidal or subtidal habitats of the San Juan Islands consistently prefer mussels over $T$. transversa and this species can be partly unpalatable due to its toxic tissue (Mauzey et al. 1968, Thayer 1985). This brachiopod does co-occur with the epibyssate bivalve Pododesmus macrochisma, which is commonly attacked by predatory gastropods, sea stars and other predators (Mauzey et al. 1968, Spight et al. 1974, Schmitt 1987). Higher drilling frequencies of bivalves than brachiopods in past and present-day non-cryptic environments (Hoffmeister et al. 2004, Simões et al. 2007) also imply low predation pressure on brachiopods and counteract the hypothesis of negative effects of escalation on brachiopod ecology (Kowalewski et al. 2005, but see Leighton 1999).

However, it was hypothesized that grazing on juveniles and small-sized individuals rather than predation on adults can have negative effects on brachiopod ecology. High consumer pressure can still limit Terebratalia transversa (and brachiopods in other environments), due to negative effects of unselective grazing or its bulldozing side-effects. Vermeij (1977) has suggested that brachiopods are more negatively affected by grazing than epifaunal bivalves and Asgaard \& Stentoft (1984) suggested that the restriction of micromorphic brachiopods to crevices and cryptic habitats can be related to the high grazing pressure in shallow environments (see also Asgaard \& Bromley 1991). In addition, it also has been suggested that abundance of the large-sized brachiopod Terebratulina septentrionalis is negatively affected by incidental effects of strong grazing pressure (Noble et al. 1976, Witman \& Cooper 1983, Logan et al. 1984, Collins 1991). This grazing hypothesis remains unexplored for brachiopods and epifaunal bivalves that co-occur within one habitat, and for large-sized brachiopods other than $T$. septentrionalis that live in different habitats. Therefore, in order to compare effects of grazing disturbance on abundance of the large-sized brachiopod T. transversa and co-occurring sessile epifauna, in this study I analyzed hard-bottom epifaunal communities of the San Juan Islands.

First, I evaluated whether abundance of Terebratalia transversa is more negatively affected by biotic disturbance (measured as proportion of bare space and coralline crusts) and more positively affected by the availability of crevices than abundance of the epibyssate bivalve Pododesmus macrochisma. Second, I assessed differences in responses to surface rugosity between juveniles and adults because grazing effects should preferentially affect juvenile and small-sized individuals (i.e. large-sized individuals can achieve refuge when they become less vulnerable to grazing).
Terebratalia transversa and the anomiid bivalve Pododesmus macrochisma are the most common representatives of brachiopods and sessile bivalves in hard-bottom habitats of the San Juan Islands. Manipulative experiments and observations have shown that brachiopods either do not settle on settlement panels, or are the last to colonize (Thayer 1977). Therefore, a non-manipulative approach based on measurements of percent cover and density of $T$. transversa and P. macrochisma sampled in natural substrates varying in surface rugosity and bare space was used here.

\section{MATERIALS AND METHODS}

Field sites and data. Terebratalia transversa mainly occupies rocky subtidal habitats exceeding $20 \mathrm{~m}$ in depth in the San Juan Islands and is less common on downward-facing surfaces of boulders and cobbles, and on vertical rock walls in intertidal habitats (Thayer 1977). The slope topography of San Juan Channel was substantially shaped by glaciers and is thus characterized by highly uneven topography with high substrate complexity, steep, rocky slopes, and large boulders. Habitats were subdivided here into 2 zones according to the presence of red algae. Shallow subtidal habitats included rocky bottoms with abundant foliose, fleshy and filamentous red algae, coralline red algae, and bryozoans. Deep subtidal habitats were characterized by rocky bottoms with hydroids, barnacles, ascidians, bryozoans, mollusks, and brachiopods.

In this study, rocky substrates larger than $25 \mathrm{~cm}^{2}$ were sampled in: (1) intertidal and shallow subtidal habitats (<20 $\mathrm{m}$ in depth) of Mitchell Bay and Mosquito Pass (MB/MP) on the NW margin of San Juan Island, and (2) deep subtidal habitats of San Juan Channel (SJC, between 20 and $110 \mathrm{~m}$ in depth, Fig. 1). Intertidal habitats were sampled on a cobble beach in Mitchell Bay (MB1) in an approximately $100 \mathrm{~cm}$ thick zone near mean lower low water (MLLW). Rock wall surfaces reaching $100 \mathrm{~cm}^{2}$ in area were photographed in the field. Undersides and upper sides of boulders and cobbles that were collected from meter-scale crevices under cliff walls were photographed separately when placed in a flow tank in the laboratory.

Small rocks (mainly cobbles) from subtidal habitats were sampled by a dredge at 7 sites. At least 20 rocks per site, with a surface area exceeding $25 \mathrm{~cm}^{2}$, were randomly selected from the dredge and placed in a bucket filled with seawater (mean $=48 \mathrm{~cm}^{2}$, maximum $=150 \mathrm{~cm}^{2}$ ). An upper side of each rock was photographed in the laboratory after it was placed in a flow tank. The dredged rocks were sampled within 1 depth along a 50 to $100 \mathrm{~m}$ transect parallel to shore. Shallow subtidal habitats were represented by 

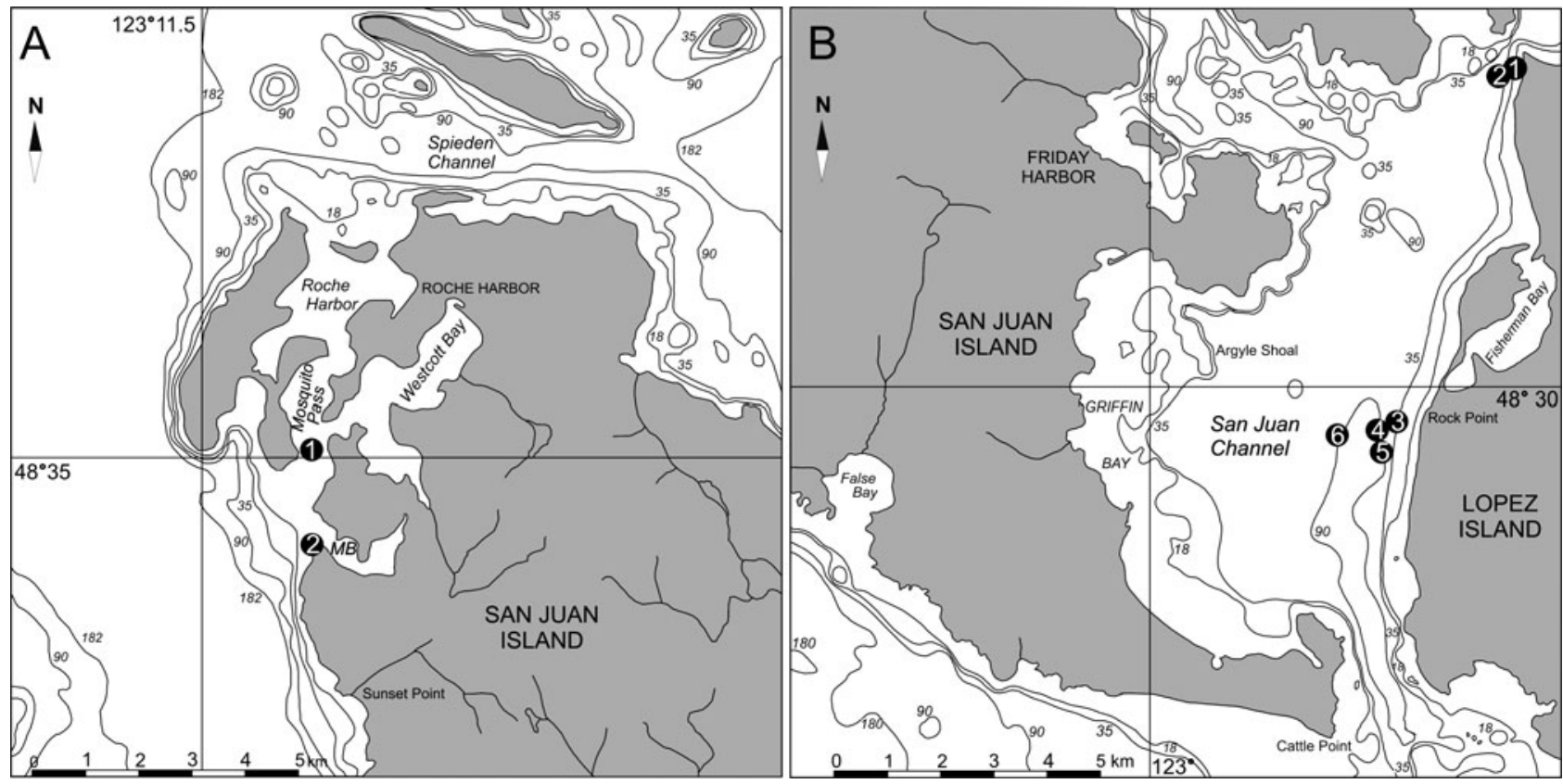

Fig. 1. Geographic location of (A) 2 sampling sites in intertidal and shallow subtidal habitats in Mosquito Pass (1) and Mitchell Bay $(\mathrm{MB} ; 2)$, and (B) 6 sampling sites in deep subtidal habitats of San Juan Channel (San Juan Islands, Washington, USA)

1 dredged site (MB2, 13 to $17 \mathrm{~m}$ in depth) in the Mosquito Pass on the northern margin of the San Juan Island (Fig. 1A). Boulders and cobbles were dominated by coralline red algae, non-coralline red algae and sheet bryozoans associated with dense populations of the sea urchin Strongylocentrotus franciscanus. Small rocks from deep subtidal habitats were sampled by dredge at 6 sites on the eastern side of San Juan Channel along the western margin of Lopez Island (Fig. 1B). The sites SJ1 and SJ2 represented the shallowest sampled sites (22 and $46 \mathrm{~m}$ in depth), and small rocks were mainly occupied by Pododesmus macrochisma and small-sized barnacles Balanus balanus and Balanus rostratus. Terebratalia transversa was absent. The sites SJ3, SJ4 and SJ5 represented a bathymetric transect along a steep topographic slope near the Rock Point (50, 73 and $75 \mathrm{~m}$ in depth). Small rocks were dominated by small-sized barnacles, solitary ascidians, $P$. macrochisma, the suspension-feeding gastropod Calyptraea fastigiata, the blind limpet Cryptobranchia concentrica, and the brachiopod T. transversa. The deepest site sampled near the Rock Point (SJ6, $110 \mathrm{~m}$ in depth) was almost exclusively dominated by the giant acorn barnacle $B$. nubilus, commonly colonized by $T$. transversa. The sea urchin Strongylocentrotus droebachiensis is very abundant in deep subtidal habitats of San Juan Channel.

The population density of Terebratalia transversa and Pododesmus macrochisma was estimated by counting the number of individuals per $25 \mathrm{~cm}^{2}$. Percent cover of encrusters, proportion of bare space and coralline crusts, and surface covered by biofilms were estimated on digitized rocks with the ImageJ software. The percent cover of encrusters was estimated by drawing an outline along each organism and computing its enclosed area up to nearest $0.1 \mathrm{~cm}^{2}$. The percent cover of all encrusters can exceed $100 \%$ because small-sized encrusters commonly coated other taxa attached to small rocks. The proportion of bare space was estimated by outlining bare rock. The mean of the area surveyed per site was $2100 \mathrm{~cm}^{2}$, with a range of 620 to $3600 \mathrm{~cm}^{2}$.

Percent cover of each of 28 sessile groups was estimated from photographs. These included the barnacles Balanus balanus, B. rostratus, and B. nubilus, the anomiid bivalve Pododesmus macrochisma, the vermetid gastropod Petaloconchus sp., the brachiopod Terebratalia transversa, sheet bryozoans, and 2 erect bryozoans (Dendrobeania sp. and 1 undetermined taxon, excluding the canopy-forming erect bryozoan Bugula stolonifera), 6 encrusting sponges (Halichondria sp., Ophlitaspongia sp., and 4 undetermined taxa), sabellariid, chaetopterid, serpulid, and spirorbid polychaetes, solitary and compound ascidians (Pyura haustor, Boltenia villosa, Didemnum sp., Diplosoma sp., Chelyosoma sp., Metandrocarpa sp.), 2 coral taxa, non-coralline and coralline red algae, and green algae.

Substrates without rugosity were characterized by flat or low-relief rocks lacking crevices (5 to $10 \mathrm{~mm}$ in depth). Substrates with rugosity were characterized by presence of $\mathrm{cm}$-scale crevices (rocky irregularities and 
aggregations of polychaetes, ascidians, and barnacles), with crevices attaining 5 to $10 \mathrm{~mm}$ in depth and diameter and with inter-crevice distance less than 10 to $20 \mathrm{~mm}$. The proportion of bare space and of crusts of coralline red algae represents an indirect correlative measure of disturbance (see 'Discussion'). The bare space was treated as a continuous variable in generalized linear models (GLM) and as a categorical variable in multivariate analyses. Substrates were divided into 2 groups with less than or greater than $40 \%$ bare space. Attachment sites of Terebratalia transversa and Pododesmus macrochisma, their rugosity (i.e. a flat surface, or a crevice exceeding $5 \mathrm{~mm}$ in depth), and valve lengths of $T$. transversa and $P$. macrochisma individuals were recorded on small rocks dredged in deep subtidal habitats. Therefore, analyses of size patterns of $P$. macrochisma and $T$. transversa were restricted to the subset of samples and did not incorporate intertidal and shallow subtidal habitats.

Data analysis. Univariate and multivariate analyses were performed at 2 spatial extents, within 3 habitats, including (1) intertidal and shallow subtidal rocks, (2) intertidal and shallow subtidal rock walls, and (3) deep subtidal rocks; and within 5 sites nested within the deep subtidal habitat. Abundance data of Terebratalia transversa and Pododesmus macrochisma were analyzed as densities in univariate analyses. In multivariate analyses, abundance data were represented by percent covers of encrusters because sessile taxa are represented by solitary and colonial groups.

GLM less prone to assumptions of linear regression models were used to assess effects of rugosity and bare space on density of Terebratalia transversa and Pododesmus macrochisma within habitats and within deep subtidal sites. I evaluated whether 1 predictor variable (e.g. rugosity) did not explain any of the variation in abundance, beyond the variation explained by the second predictor variable (e.g. bare space). GLM are based here on the log link function (describing how the mean of the density depends on the predictor variable) and the quasi-Poisson variance function (describing how the variance of the density depends on its mean), which assumes that dispersion of individuals is not random (Kindt \& Coe 2005). To assess relative predictive power of rugosity and bare space, their slopes (normalized to $Z$-scores to account for their different magnitude and dispersion) were compared within habitats and within sites. The amount of total deviance explained by GLM is comparable to the $\mathrm{R}^{2}$ of a standard linear regression. GLM evaluating effects of rugosity and bare space on $T$. transversa and $P$. macrochisma used density as the response variable.

Univariate analyses based on means with $95 \%$ bootstrapped confidence intervals were used to evaluate: (1) whether percent cover of Terebratalia transversa and Pododesmus macrochisma differs between substrates with and without rugosity under constant proportion of bare space, and between substrates with low and high bare space under constant rugosity; and (2) whether $T$. transversa and $P$. macrochisma differ in size between crevices and flat surfaces.

To evaluate differences in overall community composition between substrates differing in the rugosity and bare space within 3 habitats and within 6 sites, I analyzed similarities (2-way analysis of similarities, ANOSIM) based on the Bray-Curtis coefficient. Percent covers of Pyura haustor and Balanus nubilus were removed from analyses evaluating effects of rugosity. In addition, non-metric multidimensional scaling (NMDS) based on Bray-Curtis similarities was used to examine differences in community composition and relationships between percent covers of encrusters within deep subtidal sites. I adopted the approach of Oksanen et al. (2005) to resolve the indeterminacy of scaling and orientation of axes in NMDS and to ordinate sample and taxon scores into 2-dimensional space. Two-way ANOSIM was performed with PRIMER software (Clarke \& Warwick 2001), and GLM and NMDS with the R-language (R Development Core Team 2007).

\section{RESULTS}

\section{Univariate analyses}

In intertidal and shallow subtidal habitats, the effects of rugosity on Terebratalia transversa density were significantly positive both on small rocks and on rock walls (Table 1). The effects of bare space on T. transversa density were insignificant on small rocks and on rock walls (Fig. 2A,B, Table 1). The proportion of bare space had significantly positive effects on density of Pododesmus macrochisma in intertidal and shallow subtidal habitats with rock walls, and insignificant effects on small rocks (Fig. 2D,E, Table 1), and the effects of rugosity on $P$. macrochisma density were insignificant. In deep subtidal habitats, $T$. transversa decreased significantly in density with increasing bare space and with decreasing rugosity (Table 1 , Fig. 2C). In contrast to $T$. transversa, the density of P. macrochisma decreased significantly with rugosity, but was not significantly affected by bare space in deep subtidal habitats (Fig. 2F).

Within-site effects of bare space on density of Terebratalia transversa were significantly negative in 2 deep subtidal sites (Table 1). The effects of rugosity were significantly positive in 2 deep subtidal sites. Within-site effects of bare space on density of Pododesmus macrochisma were highly variable but mostly 
insignificant in 5 deep subtidal sites (Table 1). Although bare space decreases on topographically complex substrates, univariate analyses indicate that both bare space and rugosity had unique effects on density of $T$. transversa and P. macrochisma, and that $T$. transversa and $P$. macrochisma had different responses to rugosity and bare space.

\section{Multivariate analyses}

Two-way ANOSIM showed that the overall community structure was affected by between-substrate differences in rugosity and bare space (Table 2). Terebratalia transversa co-occurred with non-coralline red algae, the bryozoan Dendrobeania sp., and chae-

Table 1. Terebratalia transversa, Pododesmus macrochisma. Generalized linear models evaluating effects of rugosity and bare space on density at 2 spatial extents: within habitats and sites. Note that these within-site analyses were restricted to a subset of sites because sites SJ1 and SJ2 do not contain T. transversa, and site SJ6 is invariably characterized by presence of rugose substrates with dominance of Balanus nubilus. Slope values in bold correspond to significant results after Bonferroni correction

\begin{tabular}{|c|c|c|c|c|c|}
\hline & Explained deviance & Slope & SE & $t$ & $\mathrm{p}$ \\
\hline \multicolumn{6}{|l|}{ HABITAT } \\
\hline \multicolumn{6}{|l|}{ Terebratalia transversa } \\
\hline Intertidal - shallow subtidal walls & 0.37 & & & & \\
\hline Rugosity & & 1.41 & 0.31 & 4.48 & $<0.0001$ \\
\hline Bare space & & 0.0002 & 0.2 & 0.001 & 0.99 \\
\hline Intertidal - shallow subtidal rocks & 0.27 & & & & \\
\hline Rugosity & & 0.88 & 0.34 & 2.58 & 0.012 \\
\hline Bare space & & -0.4 & 0.29 & -1.37 & 0.17 \\
\hline Deep subtidal rocks & 0.33 & & & & \\
\hline Rugosity & & 0.87 & 0.2 & 4.45 & $<0.0001$ \\
\hline Bare space & & -0.82 & 0.19 & -4.35 & $<0.0001$ \\
\hline \multicolumn{6}{|l|}{ Pododesmus macrochisma } \\
\hline Intertidal - shallow subtidal walls & 0.55 & & & & \\
\hline Rugosity & & -0.27 & 0.16 & -1.71 & 0.09 \\
\hline Bare space & & 0.67 & 0.09 & 7.22 & $<0.0001$ \\
\hline Intertidal - shallow subtidal rocks & 0.09 & & & & \\
\hline Rugosity & & -0.36 & 0.22 & -1.66 & 0.1 \\
\hline Bare space & & 0.28 & 0.17 & -1.7 & 0.1 \\
\hline Deep subtidal rocks & 0.03 & & & & \\
\hline Rugosity & & -0.26 & 0.1 & -2.6 & 0.0099 \\
\hline Bare space & & -0.07 & 0.12 & -0.57 & 0.57 \\
\hline \multicolumn{6}{|l|}{ SITE } \\
\hline \multicolumn{6}{|l|}{ Terebratalia transversa } \\
\hline Site SJ3 & 0.18 & & & & \\
\hline Rugosity & & 0.26 & 0.35 & 0.74 & 0.46 \\
\hline Bare space & & -0.7 & 0.36 & -1.93 & 0.061 \\
\hline Site SJ4 & 0.46 & & & & \\
\hline Rugosity & & 1.9 & 0.69 & 2.74 & 0.008 \\
\hline Bare space & & -1.07 & 0.38 & -2.8 & 0.007 \\
\hline Site SJ5 & 0.41 & & & & \\
\hline Rugosity & & 0.99 & 0.27 & 3.72 & 0.00045 \\
\hline Bare space & & -0.73 & 0.36 & -2.03 & 0.047 \\
\hline \multicolumn{6}{|l|}{ Pododesmus macrochisma } \\
\hline Site SJ1 & 0.005 & & & & \\
\hline Rugosity & & 0.02 & 0.17 & 0.09 & 0.93 \\
\hline Bare space & & -0.06 & 0.2 & -0.32 & 0.75 \\
\hline Site SJ2 & 0.009 & & & & \\
\hline Rugosity & & -0.17 & 0.55 & -0.3 & 0.77 \\
\hline Bare space & & -0.11 & 0.44 & -0.25 & 0.81 \\
\hline Site SJ3 & 0.02 & & & & \\
\hline Rugosity & & 0.09 & 0.22 & 0.41 & 0.68 \\
\hline Bare space & & 0.18 & 0.22 & 0.8 & 0.43 \\
\hline Site SJ4 & 0.2 & & & & \\
\hline Rugosity & & -0.51 & 0.15 & -3.5 & 0.0009 \\
\hline Bare space & & 0.11 & 0.2 & 0.53 & 0.6 \\
\hline Site SJ5 & 0.18 & & & & \\
\hline Rugosity & & -0.33 & 0.3 & -1.09 & 0.28 \\
\hline Bare space & & -1.14 & 0.5 & -2.29 & 0.026 \\
\hline
\end{tabular}



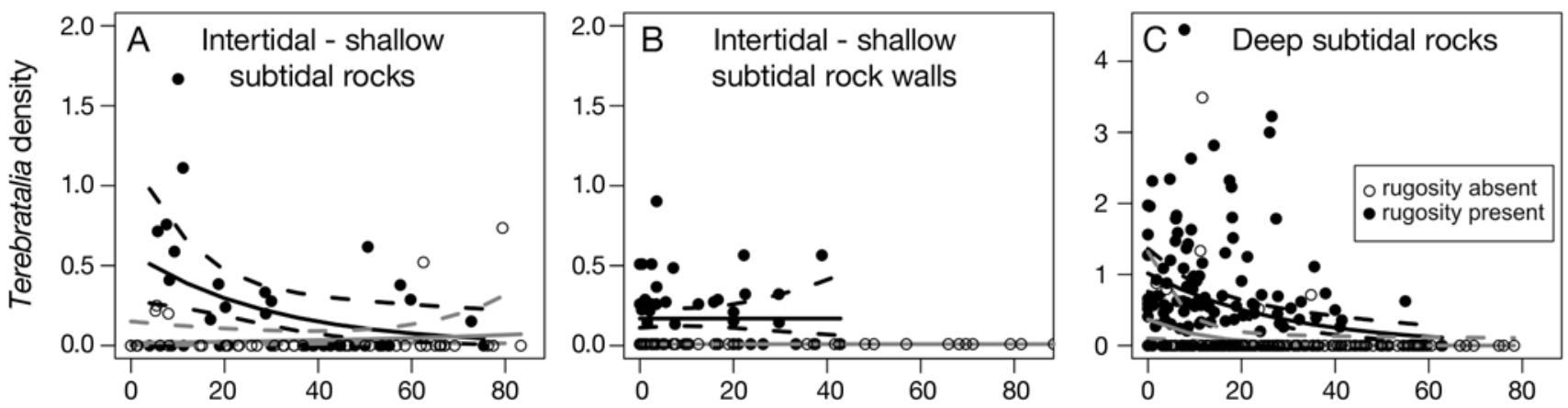

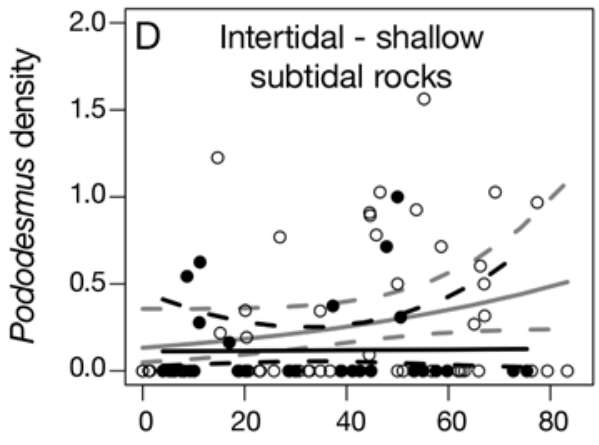

Proportion of bare space + crusts

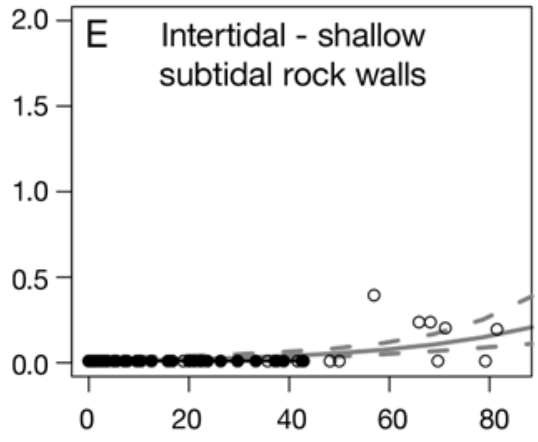

Proportion of bare space + crusts

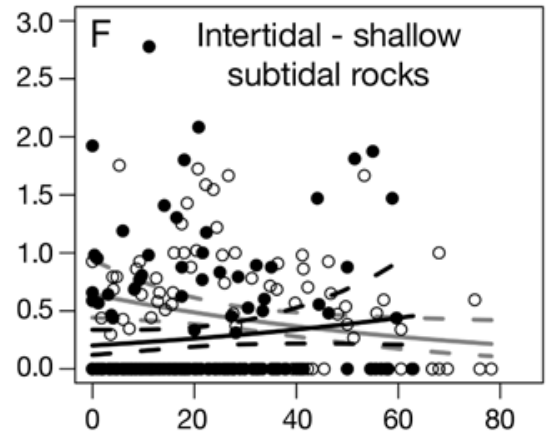

Proportion of bare space + crusts

Fig. 2. (A-C) Terebratalia transversa, (D-F) Pododesmus macrochisma. Predicted slopes and $95 \%$ confidence intervals of the relationship between density (ind. per $25 \mathrm{~cm}^{2}$ ) and bare space within 3 habitats, based on generalized linear models with the log link and the quasi-Poisson variance function. T. transversa generally declines in abundance with increasing bare space. Grey slopes correspond to substrates without rugosity and black slopes represent substrates with rugosity

topterids on rock walls with rugosity in intertidal habitats. Small-sized barnacles, sheet bryozoans, sponges, and Pododesmus macrochisma inhabited rock walls without rugosity and higher bare space (Fig. 3A,B). In intertidal and shallow subtidal habitats, T. transversa co-occurred mainly with sponges, the ascidian Didemnum sp., the bryozoan Dendrobeania sp., sheet bryozoans, and spirorbids on small rocks

Table 2. Two-way analysis of similarities (ANOSIM) showing significant differences in community composition between substrates with and without rugosity, and with low and high bare space at 2 spatial extents. $\mathrm{p}$-values in bold represent significant results after Bonferroni correction. $\mathrm{p}$-values in italics represent results insignificant after Bonferroni correction

\begin{tabular}{|lccccc|}
\hline Habitat/site & Bare space & \multicolumn{3}{c|}{ Rugosity } \\
ANOSIM & $R$ & $\mathrm{p}$ & ANOSIM & $\mathrm{p}$ \\
\hline Intertidal - shallow subtidal walls & $\mathbf{0 . 4 2}$ & $\mathbf{0 . 0 0 2}$ & $\mathbf{0 . 1 5}$ & $\mathbf{0 . 0 0 2}$ \\
Intertidal - shallow subtidal rocks & $\mathbf{0 . 1 6}$ & $<\mathbf{0 . 0 0 1}$ & $\mathbf{0 . 1 1}$ & $\mathbf{0 . 0 0 5}$ \\
Deep subtidal rocks & $\mathbf{0 . 1 5}$ & $\mathbf{0 . 0 0 1}$ & $\mathbf{0 . 3 9}$ & $<\mathbf{0 . 0 0 0 1}$ \\
Site SJ1 & $\mathbf{0 . 4 2}$ & $\mathbf{0 . 0 0 0 1}$ & $\mathbf{0 . 4 7}$ & $<\mathbf{0 . 0 0 0 1}$ \\
Site SJ2 & 0.23 & 0.026 & 0.41 & 0.018 \\
Site SJ3 & 0.08 & 0.21 & 0.1 & 0.05 \\
Site SJ4 & $\mathbf{0 . 4 1}$ & $\mathbf{0 . 0 0 7 3}$ & $\mathbf{0 . 5 7}$ & $<\mathbf{0 . 0 0 0 1}$ \\
Site SJ5 & 0.23 & 0.034 & $\mathbf{0 . 5 1}$ & $<\mathbf{0 . 0 0 0 1}$ \\
\hline
\end{tabular}

with rugosity and low bare space in intertidal and shallow-subtidal habitats. Non-coralline red algae, chaetopterids, serpulids, and P. macrochisma attained the highest percent cover on small rocks with low rugosity and high bare space (Fig. 3C,D). In deep subtidal habitats, topographically complex substrates were mainly formed by solitary ascidians and giant barnacles that commonly surrounded $T$. transversa (Figs. 3E,F \& 4A,B). In contrast, flat surfaces characterized by higher bare space were dominated by $P$. macrochisma and smallsized barnacles (Figs. 3E,F \& 4C,D).

Two-way ANOSIM and NMDS of deep subtidal sites also demonstrated consistent within-site differences in community composition between substrates differing in rugosity and bare space (Table 2, Fig. 5). NMDS plots showed that Terebratalia transversa was associated with substrates with rugosity (mainly formed by Pyura haustor and Balanus nubilus) and low bare space, in contrast to Pododesmus macrochisma, which co-occurred mainly with small-sized barnacles and sheet bryozoans on substrates without rugosity (Fig. 5). 

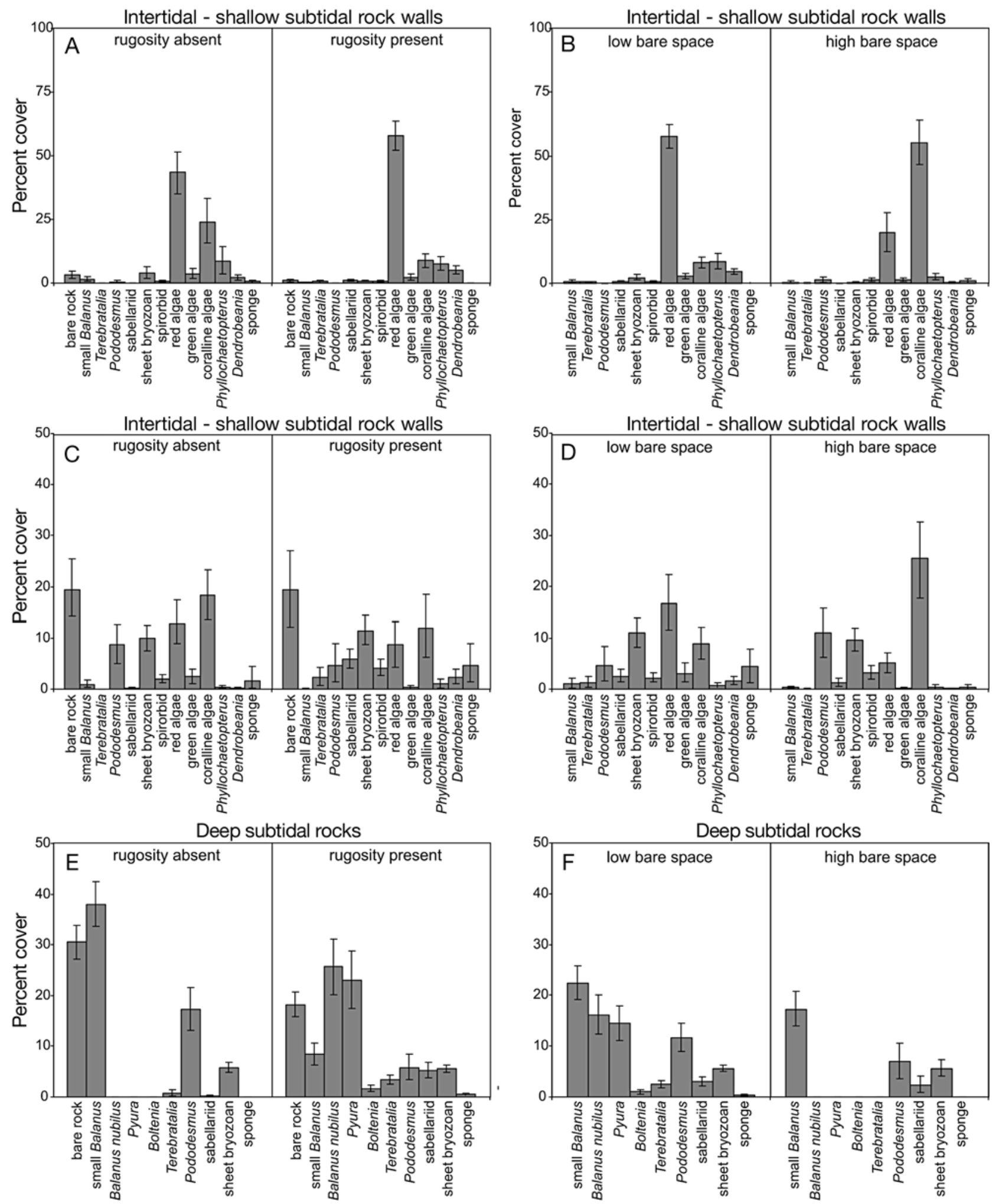

Fig. 3. Differences in percent covers of sessile benthos between substrates differing in rugosity and bare space on: (A,B) intertidal and shallow subtidal rock walls, $(\mathrm{C}, \mathrm{D})$ intertidal and shallow subtidal rocks, and (E,F) deep subtidal rocks. Terebratalia transversa is more common on rocks with rugosity; Balanus nubilus, Pyura haustor are more common on low bare space; and Pododesmus macrochisma mainly co-occurs with small barnacles on rock walls and rocks without rugosity. Error bars are $95 \%$ bootstrapped confidence intervals 

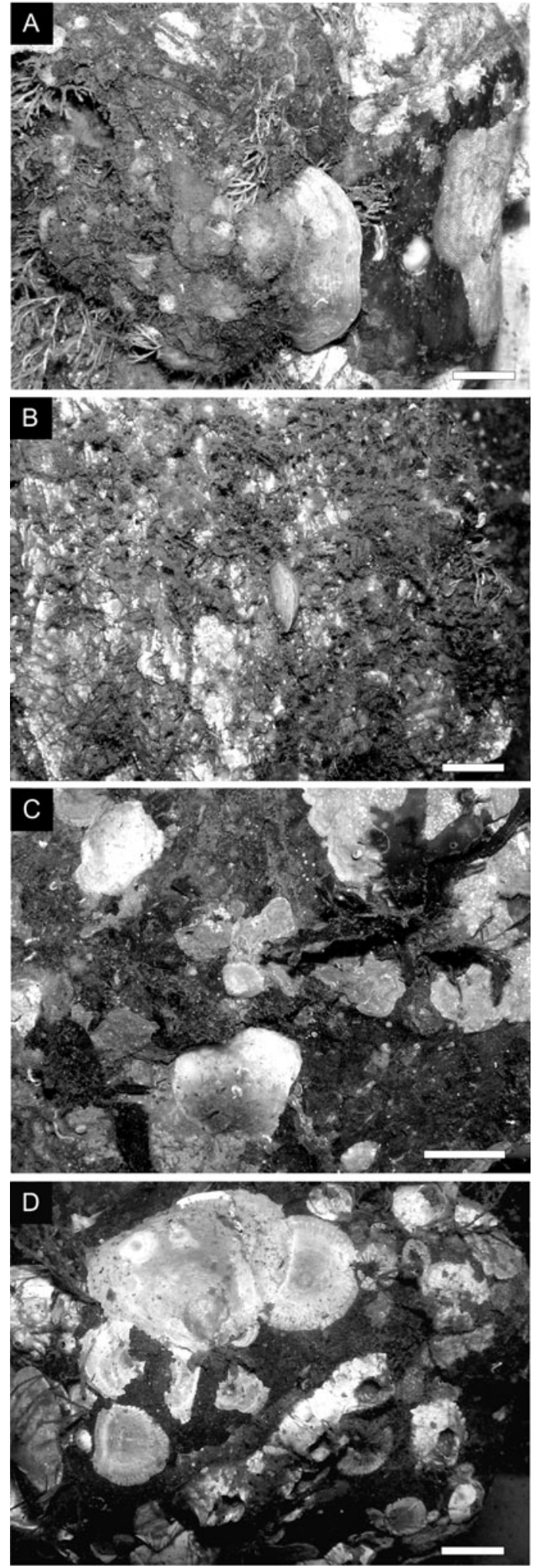

Fig. 4. (A,B) Deep subtidal rocks with rugosity formed by the ascidian Pyura haustor and the giant barnacle Balanus nubilus, and Terebratalia transversa inhabiting crevices, and $(\mathrm{C}, \mathrm{D})$ flat rocks with Pododesmus macrochisma and high bare space. Scale bars $=10 \mathrm{~mm}$
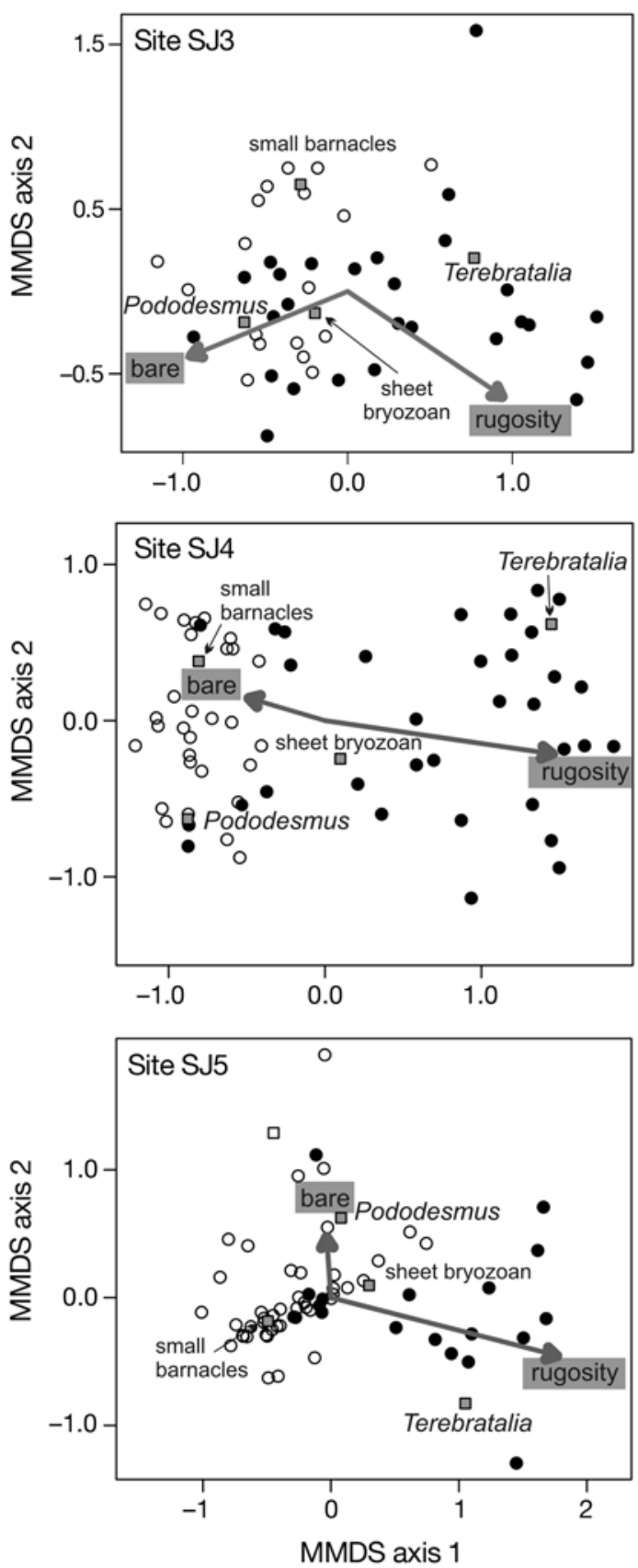

Fig. 5. Non-metric multidimensional scaling (NMDS) of 3 deep subtidal sites shows consistent differences in community composition between substrates with $(\bullet)$ and without rugosity (O). Terebratalia transversa occurs on rugose substrates with low bare space and Pododesmus macrochisma co-occurs with small barnacles on substrates with high bare space. Taxon scores were added to the Q-mode plot as weighted averages $(\square)$. Vectors of rugosity and bare space were fitted into NMDS ordination with the fitting method of Oksanen et al. (2005) to approximate the direction of gradients in bare space and rugosity. The length of the vector approximates the correlation between the environmental variable and NMDS ordination. Stress values are smaller than 0.2. Note that percent covers of Pyura haustor and Balanus nubilus were not analyzed because they define surface rugosity 


\section{Size patterns}

The comparisons of attachment sites and body size patterns in Terebratalia transversa and Pododesmus macrochisma were restricted to deep subtidal sites with more than 40 individuals. $T$. transversa was attached mainly to solitary ascidians (25\%), sabellariid polychaetes $(22 \%)$, rock surfaces $(19 \%)$, giant barnacles $(15 \%)$, and, less commonly, to conspecific shells (5\%). P. macrochisma was predominantly attached to rock surfaces $(90 \%)$. Based on non-overlapping $95 \%$ bootstrapped confidence intervals, T. transversa attained significantly lower mean shell size in crevices than on flat surfaces (Fig. 6A). Median shell size was also significantly smaller in crevices (10 to $22.4 \mathrm{~mm}$ ) than on flat surfaces (21 to $27 \mathrm{~mm}$ ) (Mann-Whitney $U$ test: site SJ3, $p=0.016$, site SJ4, $p=0.00018$, site SJ5, $\mathrm{p}=0.014$, site SJ6, $\mathrm{p}<0.0001$ ). Size-frequency distributions show that the larger shell size of T. transversa on flat surfaces than in crevices was related to higher proportion of juveniles and subadults attached to crevices (Fig. 6C). Flat surfaces were characterized by very low proportion of small-sized $T$. transversa individuals. In contrast to $T$. transversa, the median size of $P$. macrochisma was not smaller in crevices (26 to $46 \mathrm{~mm}$ ) than on flat surfaces (22 to $39 \mathrm{~mm}$, Fig. 6B).
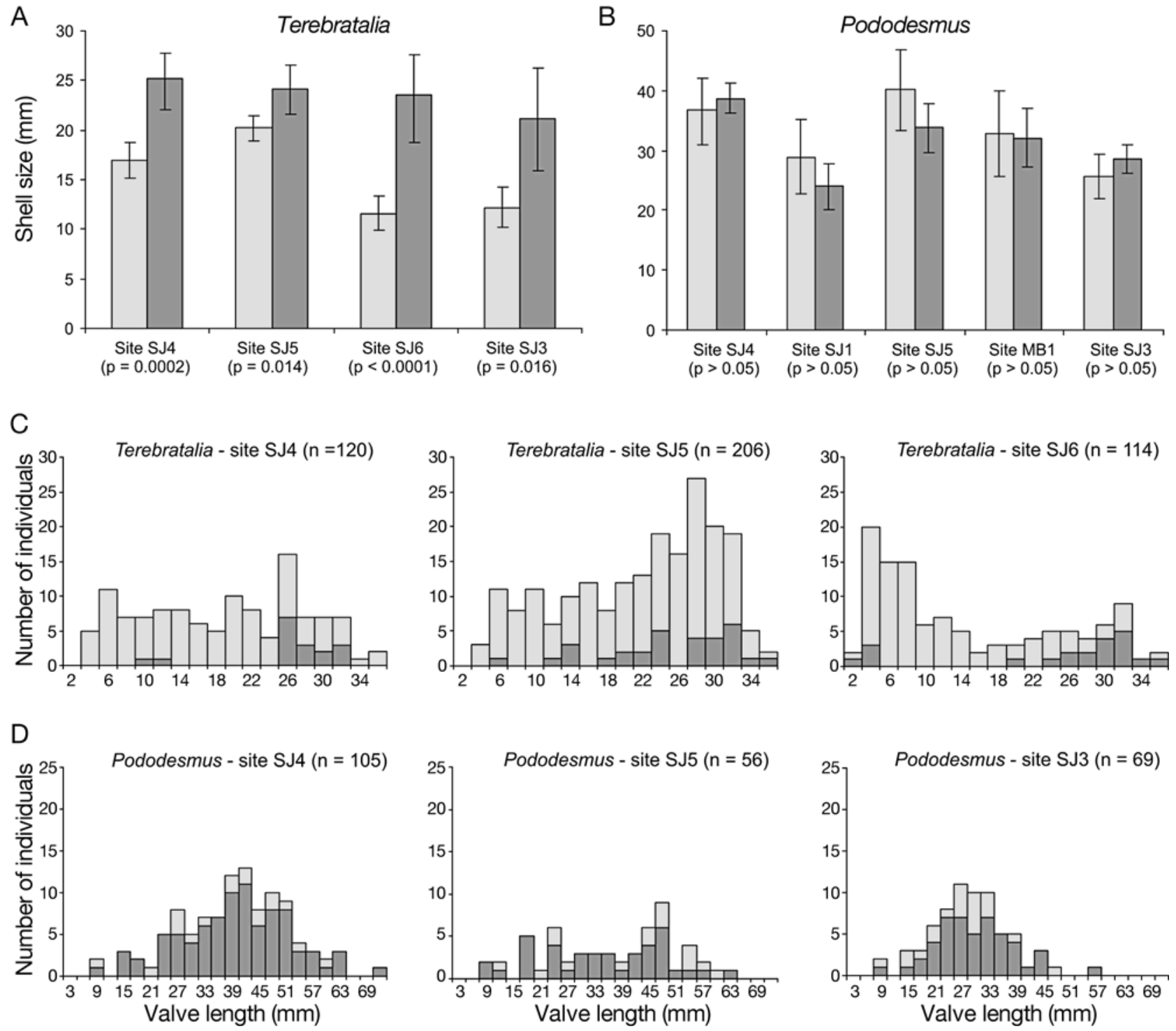

Fig. 6. (A) Terebratalia transversa attached to crevices (light grey bars) is consistently smaller than on flat surfaces (dark grey bars) in deep subtidal habitats. (B) Size differences between Pododesmus macrochisma attached to crevices and flat surfaces are insignificant. (C) Size-frequency distributions show that small-sized individuals of $T$. transversa were mainly attached to crevices (light grey bars) and rarely to flat surfaces (dark grey bars). (D) Size-frequency distributions of $P$. macrochisma do not differ between crevices and flat surfaces. p-values correspond to significance levels of Mann-Whitney $U$-test 
Within deep subtidal sites, P. macrochisma thus did not show any consistent size differences in size-frequency distributions between substrates differing in the degree of rugosity (Fig. 6D).

\section{DISCUSSION}

\section{Effects of rugosity and disturbance on abundance}

Terebratalia transversa mainly utilized crevices within topographically complex substrates and its distribution patterns might partly be explained by varying availability of substrates with high rugosity. The substrate complexity can also decrease the biotic disturbance by inhibiting access of consumers to prey and can cause positive relationship between brachiopod abundance and substrate rugosity even when brachiopod larvae do not strongly prefer crevices as sites of settlement (Keough \& Downes 1982, Holt 1984, Connell 1985, Menge et al. 1985, 1986, Petraitis 1990, Maldonado \& Uriz 1998). GLM indicated that the presence of rugosity explains a significant amount of variation in abundance of $T$. transversa that is unexplained by bare space. Rugophilic settlement of $T$. transversa larvae may thus contribute to the spatial variation in the abundance of $T$. transversa and its higher abundance in crevices. Stricker \& Reed (1985) found that larvae of $T$. transversa tend to settle in darkened, wrinkled regions of various substrates, showing photonegative and rugophilic behavior in a laboratory. In addition, larvae of other articulate brachiopods also exhibit selective settlement choices (Pennington et al. 1999), and, generally, photonegative and/or rugophilic behavior prior to settlement (Noble et al. 1976, Witman \& Cooper 1983). In contrast to T. transversa, Pododesmus macrochisma was negatively affected by surface rugosity, implying contrasting settlement behavior and reduced ability in utilization of rugose substrates.

The proportion of bare space and of crusts of coralline red algae generally represents a measure of disturbance. The presence of crust-forming coralline red algae depends on presence of grazers that inhibit overgrowth of slow-growing crusts by fast-growing algae (Steneck et al. 1991, Sebens 1985). Bare rocks are often the consequence of the combined effects of biological and physical disturbance (Sousa 1980, Chapman 2002). In this study, within-site analyses controlled for the between-habitat variation in physical disturbance because deep subtidal sites are characterized by medium-energy conditions and the presence of muddy sediment among small rocks. In addition, low and insignificant relationships between rock size and bare space in both shallow (Spearman's rank correla- tion coefficient, $\left.r_{S}=-0.2, p=0.06\right)$ and deep $\left(r_{S}=-0.14\right.$, $\mathrm{p}=0.02$ ) habitats suggest that the bare space (plus coralline crusts) resulted more from the intensity of biotic disturbance (i.e. predation, herbivory, and grazing) than physical disturbance (McGuinness 1987).

Controlling for the effects of rugosity in univariate and GLM analyses, Terebratalia transversa and Pododesmus macrochisma differed in response to biotic disturbance. T. transversa generally attained higher abundance with low bare space, suggesting that $T$. transversa was less resistant to biotic disturbance than P. macrochisma. Reduced abundance of T. transversa on rugose substrates with high bare space indicates that utilization of physical refuges such as crevices can reduce, but does not eliminate, postsettlement mortality of $T$. transversa. Even though small rocks and rock walls may provide some escape from biotic disturbance by reducing access to grazers (Sebens 1985, Knott et al. 2004, Bowden et al. 2006), substrates with crevices may still provide insufficient refuges under heavy biotic disturbance. In addition, multivariate analyses indicated that bare space positively affected abundances of other sessile taxa, such as small-sized barnacles.

The negative effects of grazers on Terebratalia transversa are also indicated by virtual absence of T. transversa on exposed intertidal and shallow subtidal substrates dominated by crusts of coralline red algae, which generally result from grazing (Lubchenco et al. 1984, Littler et al. 1995). In the San Juan Islands, both limpets and the chiton Katharina tunicata can exert a strong impact on community composition in intertidal habitats (Duggins \& Dethier 1985, Steneck et al. 1991). Grazing by sea urchins is also one of the major causes of juvenile mortality of benthic invertebrates in subtidal habitats (Ebert 1977, Karlson 1978, Ayling 1981). The sea urchin Strongylocentrotus droebachiensis occurs in high abundances in deep subtidal sites of San Juan Channel and co-occurs with T. transversa. This species has a strong negative impact on grazing-susceptible species in the eastern Atlantic (Sebens 1985, Witman 1985, Briscoe \& Sebens 1988, Lauzon-Guay \& Scheibling 2007) and can be a candidate for grazing pressure on small-sized individuals of T. transversa in depths with rare chitons and limpets and without macroalgae.

\section{Effects of rugosity and disturbance on size patterns}

The differential response to biotic disturbance was supported by size-frequency distributions that imply differences in survivorship of juveniles of Terebratalia transversa and Pododesmus macrochisma between crevices and flat substrates. Although T. transversa 
juveniles grow relatively rapidly (approximately $6 \mathrm{~mm}$ $\mathrm{yr}^{-1}$ ), individuals larger than $10 \mathrm{~mm}$ are already sexually mature (Thayer 1977). The typical size of P. macrochisma at sexual maturity is poorly known but juveniles of other species of the genus Pododesmus are smaller than $20 \mathrm{~mm}$ (Yamaguchi 1998). Small-sized individuals of $T$. transversa were frequently underrepresented on flat substrates, indicating higher juvenile mortality on flat surfaces than in crevices because juveniles and subadults on flat substrates should be more prone to grazing. Higher juvenile mortality on flat substrates thus might be caused by unselective grazing that mainly affects small-sized juvenile and subadult individuals $(<10 \mathrm{~mm})$ because the removal force is partly a function of the maximum crosssectional area of the brachiopod shell and the attachment strength by pedicle partly increases with increasing pedicle diameter (Thayer 1975). Adults of T. transversa can become less vulnerable to grazing because individuals larger than $10 \mathrm{~mm}$ on flat substrates reach equally large or larger sizes than individuals attached to crevices. This supports the hypothesis that biotic disturbance is driven by grazing effects on juveniles and small-sized individuals rather than by predation on adults. However, other experiments and observations are needed to support the hypothesis that the higher abundance of large-sized brachiopods in crevices is related to effects of biotic disturbance and is not a pure consequence of rugophilic settlement preference.

\section{Associational refuges of Terebratalia transversa}

Although Terebratalia transversa generally did not dominate on substrates in terms of its percent cover, space limitation probably did not affect $T$. transversa because its abundance positively covaried with percent cover of other encrusters and its individuals were rather frequently attached to large and abundant habitat-modifiers such as Pyura haustor and Balanus nubilus. The close association of $T$. transversa with aggregations of $P$. haustor and $B$. nubilus, which form dense populations in deep subtidal habitats, indicates that the principal means of grazing avoidance in such habitats can be represented by associational refuges. $P$. haustor and B. nubilus are large and long-lived sessile invertebrates (Sherrard \& LaBarbera 2005), and their high-density self-perpetuating aggregations can probably reduce grazing in comparison to areas where their population density is low. Juvenile solitary ascidians are negatively affected by grazing gastropods, algal overgrowth and high sedimentation, but $P$. haustor is predation- and grazing-resistant in the adult stage (Young \& Chia 1984, Young 1986). Importantly, this species provides refuge for other grazing-susceptible taxa such as the erect bryozoan Bugula stolonifera and the solitary ascidian Boltenia villosa. In subtidal habitats of the western Atlantic, Bugula is highly susceptible to predators and its survival is substantially enhanced in crevices (Walters 1992, Walters \& Wethey 1996). B. stolonifera co-occurred with $T$. transversa and was commonly attached to $P$. haustor and $B$. nubilus in San Juan Channel, and was rare on substrates with high bare space. B. villosa was attached also almost exclusively to $P$. haustor, which possesses a thick leathery tunic with sediment inclusions and sharp microscopic spines around its siphons that provide defense mechanisms limiting the predatory snail Fusitriton oregonensis and other predators (Young $1985,1986,1989)$. The association of $B$. villosa with the invulnerable ascidian $P$. haustor represents an associational refuge not affected by foraging, even when its predator co-occurs in the same habitat (Young 1986). Therefore, high abundance of T. transversa individuals attached to $P$. haustor can also enhance its survival in predation-free sites.

\section{Effects of juvenile ecology on distribution patterns}

Although Terebratalia transversa can reach lower percent cover than Pododesmus macrochisma on rugose substrates, differences in their responses to rugosity and biotic disturbance indicate that they trade-off abilities to resist disturbance and to utilize complex substrates. In the adult stage, T. transversa and $P$. macrochisma have similar life habits because both are suspension feeders that feed on phytoplankton and other particles of similar size, are fixed by pedicle or calcified byssus to a firm substrate, and are unable to rotate in the adult stage (LaBarbera 1977, 1981). T. transversa is attached to a substrate with a pedicle that attains about $5 \mathrm{~mm}$ in diameter in the adult stage and does not require unlimited substrate area for attachment. P. macrochisma is attached to a substrate with stout, calcified byssus that forms a solid cylinder attaining about $10 \mathrm{~mm}$ in diameter in the adult stage. $P$. macrochisma requires a large flat area for attachment because the lower right valve has to lie flat against the substrate and the valve margins are mostly supported by the substrate to inhibit dislodgment (Bourget et al. 1994). The flat valves firmly attached to a surface along the whole attachment area can also explain its higher resistance to grazing pressure. Once dislodged from a substrate by disturbance, juvenile brachiopods are not able re-attach to their substrate and are thus very susceptible to grazinginduced post-settlement mortality. In contrast, juvenile P. macrochisma up to $10 \mathrm{~mm}$ in size can detach and 
move from their substrate after early settlement (Yonge 1977, Yamaguchi 1998). This post-settlement mobility of byssally-cemented anomiids can substantially enhance their juvenile survivorship on hard substrates in comparison to brachiopods (Yamaguchi 1998).

It is possible that the differential response of pedunculate brachiopods and epibyssate mollusks to increased grazing on evolutionary time scales is related to the differences in their juvenile ecology because grazing on juveniles can represent a substantial source of abundance variations of sessile invertebrates in present-day benthic communities (Osman \& Whitlatch 1995, 2004). Marine herbivores such as chitons, limpets and sea urchins, feeding on multicellular attached plants and able to excavate calcareous substrates, originated or substantially increased in abundance in hard-bottom communities during the Late Mesozoic, as did the diversity of nongeniculate coralline algae (Steneck 1983, Aguirre et al. 2000, Vermeij \& Lindberg 2000). This change probably led to the increase in grazing effects that negatively affected survival of brachiopod juveniles, in contrast to epibyssate juvenile bivalves, which can move and re-attach after dislodgment. On long time scales, the escalation in grazing and bulldozing pressure on brachiopod juveniles might thus primarily contribute to brachiopod evolutionary decline in hard-bottom environments characterized by rocky boulders, metazoan reefs, and carbonate sea-floors. This is in contrast to the post-Paleozoic increase in predation pressure on adult sessile benthos that affected brachiopods only secondarily (Kowalewski et al. 2005).

\section{CONCLUSIONS}

Univariate and multivariate analyses showed that rugosity had positive effects and bare space had negative effects on abundance of the brachiopod Terebratalia transversa. GLM showed that both rugosity and bare space had unique effects on abundance of T. transversa, implying that both selective rugophilic larval settlement and post-settlement mortality owing to intense biotic disturbance restrict individuals of T. transversa to crevices. T. transversa was affected by biotic disturbance more negatively than the co-occurring epibyssate bivalve Pododesmus macrochisma. This supports the hypothesis that brachiopods are less resistant to biotic disturbance than epifaunal bivalves in hard-bottom habitats. Notably, although average percent covers of $T$. transversa are relatively low $(<5 \%)$, its abundance increases towards structurally complex communities dominated by long-living solitary ascidians and giant barnacles.
Juveniles of Terebratalia transversa were underrepresented on flat substrates, implying their higher mortality there than in crevices. Adults of T. transversa were not larger in crevices than on flat substrates, indicating that adults became less vulnerable to disturbance. This supports the hypothesis that biotic disturbance negatively affected $T$. transversa mainly via grazing effects on juveniles and small-sized individuals. In contrast to $T$. transversa, flat valves in contact with substrate and high post-settlement mobility of Pododesmus macrochisma probably increased juvenile survivorship under intense biotic disturbance. T. transversa is not able to re-attach after larval settlement and is thus less resistant to grazing effects than the byssate bivalve $P$. macrochisma.

Although Terebratalia transversa is less preyed upon by carnivorous predators than Pododesmus macrochisma, it is affected more negatively by grazing on juveniles and small-sized individuals than P. macrochisma. This study thus supports the hypothesis that grazing negatively affects not only small-sized micromorphic brachiopods but also large-sized brachiopods, both in shallow and deep subtidal habitats, and thus the hypothesis that the decline in abundance of brachiopods on exposed substrates and preference of brachiopod larvae for cryptic habitats might be related to a heavy grazing pressure on juveniles in hardbottom habitats during the Mesozoic.

Acknowledgements. I thank the University of Washington, Friday Harbor Laboratories, Slovak Research and Development Agency (APVV-0248-07), the Slovakian VEGA Agency, and the Paleontological Society for financial support; M. Kowalewski and L.R. Leighton for supervision, discussions and critical comments; R. Osman for editorial review; and P. Harnik and 3 anonymous reviewers for critical reviews. I also thank the National Science Foundation (EAR-0345897) and the NOAA California Sea Grant Program 'Urban Oceans' for support.

\section{LITERATURE CITED}

Aberhan M, Kiessling W, Fürsich FT (2006) Testing the role of biological interactions for the evolution in mid-Mesozoic marine benthic ecosystems. Paleobiology 32:259-277

Aguirre J, Riding R, Braga JC (2000) Diversity of coralline red algae: origination and extinction patterns from the Early Cretaceous to the Pleistocene. Paleobiology 26:651-667

Asgaard U, Bromley RG (1991) Colonization by micromorph brachiopods in the shallow subtidal of the eastern Mediterranean Sea. In: MacKinnon DI, Lee DE, Campbell JD (eds) Brachiopods through time. A. A. Balkema, Rotterdam-Brookfield, p 261-264

Asgaard U, Stentoft N (1984) Recent micromorph brachiopods from Barbados: palaeoecological and evolutionary implications. Geobios 17, Supplement 1:29-37

Ayling AL (1981) The role of biological disturbance in temperate subtidal encrusting communities. Ecology 62:830-847

Bourget E, DeGuise J, Daigle G (1994) Scales of substratum heterogeneity, structural complexity, and the early establishment of a marine epibenthic community. J Exp Mar 
Biol Ecol 181:31-51

Bowden DA, Clarke A, Peck LS, Barnes DKA (2006) Antarctic sessile marine benthos: colonisation and growth on artificial substrata over three years. Mar Ecol Prog Ser 316: $1-16$

Briscoe CS, Sebens KP (1988) Omnivory in Strongylocentrotus droebachiensis (Müller) (Echinodermata: Echinoidea): predation on subtidal mussels. J Exp Mar Biol Ecol 115: $1-24$

Bush AM, Bambach RK, Daley GM (2007) Changes in theoretical ecospace utilization in marine fossil assemblages between the mid-Paleozoic and late Cenozoic. Paleobiology 33:76-97

- Chapman MG (2002) Patterns of spatial and temporal variation of macrofauna under boulders in a sheltered boulder field. Austral Ecol 27:211-228

Clarke KR, Warwick RM (2001) Change in marine communities. An approach to statistical analysis and interpretation. PRIMER-E Ltd, Plymouth

> Collins M (1991) Growth rate and substrate-related mortality of a benthic brachiopod population. Lethaia 24:1-11

Connell JH (1985) The consequences of variation in initial settlement vs post-settlement mortality in rocky intertidal communities. J Exp Mar Biol Ecol 93:11-45

> Duggins DO, Dethier MN (1985) Experimental studies of herbivory and algal competition in a low intertidal habitat. Oecologia 67:183-191

Ebert TA (1977) An experimental analysis of sea urchin dynamics and community interactions on a Rock Jetty. J Exp Mar Biol Ecol 27:1-22

Gili JM, Arntz WE, Palanques A, Orejas C and others (2006) A unique assemblage of epibenthic sessile suspension feeders with archaic features in the high-Antarctic. Deep-Sea Res II 53:1029-1052

Grange KR, Singleton RJ, Richardson JR, Hill PJ, Main W de L (1981) Shallow rock-wall biological associations of some southern fiords of New Zealand. NZ J Zool 8:209-227

Harper EM, Wharton DS (2000) Boring predation and Mesozoic articulate brachiopods. Palaeogeogr Palaeoclimatol Palaeoecol 158:15-24

> Hixon MA, Menge BA (1991) Species diversity: prey refuges modify the interactive effects of predation and competition. Theor Popul Biol 39:178-200

Hoffmeister AP, Kowalewski M, Bambach RK, Baumiller TK (2004) Drilling predation in brachiopods and bivalve mollusks from the Permian Strata of the Glass Mountains, West Texas. Acta Palaeontol Pol 49:443-459

- Holt RD (1984) Spatial heterogeneity, indirect interactions, and the coexistence of prey species. Am Nat 124:377-406

Karlson R (1978) Predation and space utilization patterns in a marine epifaunal community. J Exp Mar Biol Ecol 31: 225-239

Keough MJ, Downes BJ (1982) Recruitment of marine invertebrates: the role of active larval choice and early mortality. Oecologia 54:348-352

Kindt R, Coe R (2005) Tree diversity analysis: A manual and software for common statistical methods for ecological and biodiversity studies. www.worldagroforestry.org/ treesandmarkets/tree_diversity_analysis.asp

Knott NA, Underwood AJ, Chapman MG, Glasby TM (2004) Epibiota on vertical and on horizontal surfaces on natural reefs and on artificial structures. J Mar Biol Assoc UK 84: 1117-1130

> Kowalewski M, Hoffmeister AP, Baumiller TK, Bambach RK (2005) Secondary evolutionary escalation between brachiopods and enemies of other prey. Science 308: 1774-1777
LaBarbera M (1977) Brachiopod orientation to water movement. 1. Theory, laboratory behavior, and field orientations. Paleobiology 3:270-287

> LaBarbera M (1981) Water flow patterns in and around three species of articulate brachiopods. J Exp Mar Biol Ecol 55: 185-206

> Lauzon-Guay JS, Scheibling RE (2007) Behaviour of sea urchin Strongylocentrotus droebachiensis grazing fronts: food-mediated aggregation and density-dependent facilitation. Mar Ecol Prog Ser 329:191-204

> Leighton LR (1999) Possible latitudinal predation gradient in middle Paleozoic oceans. Geology 27:47-50

> Littler MM, Littler DS, Taylor PR (1995) Selective herbivore increases biomass of its prey: a chiton-coralline reef-building association. Ecology 76:1666-1681

Logan A (1975) Ecological observations on the Recent articulate brachiopod Argyrotheca bermudana Dall from the Bermuda platform. Bull Mar Sci 25:186-204

> Logan A, Page FH, Thomas MLH (1984) Depth zonation of epibenthos on sublittoral hard substrates off Deer Island, Bay of Fundy, Canada. Estuar Coast Shelf Sci 18:571-592

> Lubchenco J, Menge BA, Garrity SD, Lubchenco PJ and others (1984) Structure, persistence, and role of consumers in a tropical rocky intertidal community (Taboguilla Island, Bay of Panama). J Exp Mar Biol Ecol 78:23-73

Maldonado M, Uriz MJ (1998) Microrefuge exploitation by subtidal encrusting sponges: patterns of settlement and post-settlement survival. Mar Ecol Prog Ser 174:141-150

> Mauzey KP, Birkeland C, Dayton PK (1968) Feeding behavior of asteroids and escape responses of their prey in the Puget Sound region. Ecology 49:603-619

> McGuinness KA (1987) Disturbance and organisms on boulders. I. Patterns in the environment and the community. Oecologia 71:409-419

Menge BA, Lubchenco J, Ashkenas LR (1985) Diversity, heterogeneity and consumer pressure in a tropical rocky intertidal community. Oecologia 65:394-405

> Menge BA, Lubchenco J, Ashkenas LR, Ramsey F (1986) Experimental separation of effects of consumers on sessile prey in the low zone of a rocky shore in the Bay of Panama: direct and indirect consequences of food web complexity. J Exp Mar Biol Ecol 100:225-269

> Noble JPA, Logan A, Webb GR (1976) The Recent Terebratulina community in the rocky subtidal zone of the Bay of Fundy, Canada. Lethaia 9:1-17

> Novack-Gottshall PM (2007) Using a theoretical ecospace to quantify the ecological diversity of Paleozoic and modern marine biotas. Paleobiology 33:273-294

Oksanen J, Kindt R, O'Hara B (2005) The Vegan Package: R language. Available at: http://cc.oulu.fi/ jarioksa/

Osman RW, Whitlatch RB (1995) Predation on early ontogenetic life stages and its effect on recruitment into a marine epifaunal community. Mar Ecol Prog Ser 117:111-126

Osman RW, Whitlatch RB (2004) The control of the development of a marine benthic community by predation on recruits. J Exp Mar Biol Ecol 311:117-145

Peck LS (1996) Metabolism and feeding in the Antarctic brachiopod Liothyrella uva: a low energy lifestyle species with restricted metabolic scope. Proc Roy Soc Lond 263:223-228

> Peck LS, Barnes DKA, Willmott J (2005) Responses to extreme seasonality in food supply: diet plasticity in Antarctic brachiopods. Mar Biol 147:453-463

> Pennington JT, Tamburri MN, Barry JP (1999) Development, temperature tolerance, and settlement preference of embryos and larvae of the articulate brachiopod Laqueus californianus. Biol Bull 196:245-256 
Petraitis PS (1990) Direct and indirect effects of predation, herbivory and surface rugosity on mussel recruitment. Oecologia 83:405-413

R Development Core Team (2007) R: A language and environment for statistical computing. R Foundation for Statistical Computing, Vienna, Austria. Available at: www.R-project.org

Schmitt RJ (1987) Indirect interactions between prey: apparent competition, predator aggregation, and habitat segregation. Ecology 68:1887-1897

Sebens KP (1985) Community ecology of vertical walls in the Gulf of Maine, USA: small scale processes and alternative community states. In: Moore PG, Seed R (eds) The ecology of rocky coasts. Columbia University Press, New York, p 346-371

Sherrard KM, LaBarbera M (2005) Form and function in juvenile ascidians. I. Implications of early juvenile morphologies for performance. Mar Ecol Prog Ser 287:127-138

Simões MG, Rodrigues SC, Kowalewski M (2007) Comparative analysis of drilling frequencies in Recent brachiopodmollusk associations from the southern Brazilian shelf. Palaios 22:143-154

Sousa WP (1980) The responses of a community to disturbance: the importance of the successional age and species' life histories. Oecologia 45:72-81

Spight TM, Birkeland C, Lyons A (1974) Life histories of small and large murexes (Prosobranchia:Muricidae). Mar Biol 24:229-242

Steneck RS (1983) Escalating herbivory and resulting adaptive trends in calcareous algal crusts. Paleobiology 9:44-61

Steneck RS, Hacker SD, Dethier MN (1991) Mechanisms of competitive dominance between crustose coralline algae: an herbivore-mediated competitive reversal. Ecology 72 : 938-950

Stricker SA, Reed CG (1985) The ontogeny of shell secretion in Terebratalia transversa (Brachiopoda, Articulata). I. Development of the mantle. J Morphol 183:233-250

Thayer CW (1975) Strength of pedicle attachment in articulate brachiopods: ecologic and paleoecologic significance. Paleobiology 1:388-399

Thayer CW (1977) Recruitment, growth and mortality of a living articulate brachiopod, with implications for the inter-

Editorial responsibility: Richard Osman,

Edgewater, Maryland, USA pretation of survivorship curves. Paleobiology 3:98-109

Thayer CW (1985) Brachiopods versus mussels: competition, predation, and palatability. Science 228:1527-1528

Vermeij GJ (1977) The Mesozoic marine revolution: evidence from snails, predators and grazers. Paleobiology 3: $245-258$

> Vermeij GJ, Lindberg DR (2000) Delayed herbivory and the assembly of marine benthic ecosystems. Paleobiology 26: $419-430$

Walters LJ (1992) Post-settlement success of the arborescent bryozoan Bugula neritina (L.): the importance of structural complexity. J Exp Mar Biol Ecol 164:55-71

Walters LJ, Wethey DS (1996) Settlement and early post-settlement survival of sessile marine invertebrates on topographically complex surfaces: the importance of refuge dimensions and adult morphology. Mar Ecol Prog Ser 137:161-171

- Witman JD (1985) Refuges, biological disturbance, and rocky subtidal communities in New England. Ecol Monogr 55: 421-445

Witman JD, Cooper RA (1983) Disturbance and contrasting patterns of population structure in the brachiopod Terebratulina septentrionalis (Couthouy) from 2 subtidal habitats. J Exp Mar Biol Ecol 73:57-79

> Yamaguchi K (1998) Cementation vs mobility: development of a cemented byssus and flexible mobility in Anomia chinensis. Mar Biol 132:651-661

Yonge CM (1977) Form and evolution in the Anomiacea (Mollusca: Bivalvia) - Pododesmus, Placuna (Placunidae Fam. Nov.). Philos Trans Roy Soc B 276:453-523

Young CM (1985) Abundance patterns of subtidal solitary ascidians in the San Juan Islands, Washington, as influenced by food preferences of the predatory snail Fusitrition oregonensis. Mar Biol 84:309-321

Young CM (1986) Defenses and refuges: alternative mechanisms of coexistence between a predatory gastropod and its ascidian prey. Mar Biol 91:513-522

Young CM (1989) Selection of predator-free settlement sites by larval ascidians. Ophelia 30:131-140

Young CM, Chia FS (1984) Microhabitat-associated variability in survival and growth of subtidal solitary ascidians during the first 21 days after settlement. Mar Biol 81:61-68

Submitted: November 20, 2007; Accepted: March 6, 2008

Proofs received from author(s): June 25, 2008 